\title{
APPLICATION OF FUNGICIDES DURING LEAF FALL TO CONTROL APPLE SCAB (VENTURIA INAEQUALIS) IN THE FOLLOWING SEASON
}

\author{
R.M. BERESFORD ${ }^{1}$, P.N. WOOD ${ }^{2}$, P.W. SHAW ${ }^{3}$ and T.J. TAYLOR ${ }^{2}$ \\ ${ }^{1}$ The Horticulture and Food Research Institute of New Zealand Ltd. \\ (HortResearch), Mt. Albert Research Centre, Private Bag 92-169, Auckland \\ 1142, New Zealand \\ ${ }^{2}$ HortResearch, Hawke's Bay Research Centre, Private Bag 1401, \\ Havelock North, Hastings 4157, New Zealand \\ ${ }^{3}$ HortResearch, Nelson Research Centre, Old Mill Road, RD3, Motueka 7198, \\ New Zealand
}

Corresponding author: rberesford@hortresearch.co.nz.

\begin{abstract}
Leaf fall applications of fungicides to reduce scab in apple orchards were investigated to reduce reliance on summer fungicides that can cause trace chemical residues on harvested fruit. Two applications of fungicides, including captan, tolyfluanid, myclobutanil and urea, were made at 10-20\% and 50-60\% leaf fall in four orchard trials in Nelson and Hawke's Bay using the cultivars 'Royal Gala', 'Braeburn', 'Fuji' and 'Sciros'/Pacific Rose ${ }^{\mathrm{TM}}$. Trial orchards received standard spring and summer fungicide programmes that complied with Integrated Fruit Production and were monitored for leaf and fruit scab in December and at harvest. Significant reductions in leaf or fruit scab occurred in three out of five comparisons involving different sites, years and cultivars, suggesting that autumn applications can reduce scab in the following season. Captan and tolyfluanid appeared most useful for autumn application. Myclobutanil should not be used because of the fungicide resistance risk. Results with urea were variable. Keywords: apple black spot, fungicides, Integrated Fruit Production.
\end{abstract}

\section{INTRODUCTION}

Control of apple scab (black spot) in orchards relies on repeated applications of fungicides during spring and summer to prevent primary infection of fruit and leaves by ascospores and secondary infection by conidia (MacHardy 1996). When fungicide applications occur during late summer to prevent pre-harvest infection, there is the risk that trace residues of fungicides may remain on the fruit at harvest. Any agrochemical residue, even below the acceptable maximum residue level, is becoming unacceptable in the market place and consequently the New Zealand apple industry aims to produce fruit with no detectable residues.

This study investigated an alternative strategy to reduce reliance on summer fungicides by applying fungicides during autumn, after the fruit has been harvested, but before the pathogen is spread about the orchard in fallen leaves. Selected fungicides that are registered for use in apples in New Zealand were applied during leaf fall in autumn; then the orchards received standard spring and summer fungicide programmes the following season. Scab was monitored the following season to determine whether the autumn applications had reduced scab incidence. 


\title{
METHODS
}

Four orchard trials were conducted in Nelson and Hawke's Bay in which fungicide treatments were applied to the trees in May 2006 and May 2007 on two occasions, at $10-20 \%$ and 50-60\% leaf fall (Table 1). The active ingredients in the fungicide products used were: captan (Captan FLO ${ }^{\circledR}$ ) at $480 \mathrm{~g} /$ litre, tolyfluanid (Euparen ${ }^{\circledR}$ Multi) at $500 \mathrm{~g} / \mathrm{kg}$, myclobutanil (Systhane ${ }^{\circledR} 400 \mathrm{WP}$ ) at $400 \mathrm{~g} / \mathrm{kg}$ and urea (Petrochem ${ }^{\circledR}$ Urea) at $>99 \%$ urea.

\section{TABLE 1: Apple field trials in Nelson and Hawke's Bay in which autumn fungicide treatments were applied twice, at $10-20 \%$ and $50-60 \%$ leaf fall.}

Trial location, cultivar, fungicide application dates Trial layout (and plot and tree age size)

Autumn fungicide treatments (two applications of each)

\section{Motueka, Nelson}

'Royal Gala' 2006-07: 24 and 31 May 2006, 12 years
Two replicates in a randomised block design (three rows of 11 trees separated by one guard row).
'Royal Gala' 2007-08: 24 and 31 May 2007, 13 years
Two replicates in a randomised block design (three rows of 11 trees separated by one guard row).
No fungicide

$2.5 \%$ urea $(50 \mathrm{~kg} / \mathrm{ha})$

tolyfluanid ( $1.25 \mathrm{~g} /$ litre $)$

myclobutanil (0.048 g/litre)
No fungicide

$2.5 \%$ urea $(50 \mathrm{~kg} / \mathrm{ha})$

captan (1.44 ml/litre)

urea plus captan as above

$\begin{array}{ll}\text { Two replicates in a } & \text { No fungicide } \\ \text { randomised block } & 2.5 \% \text { urea }(50 \mathrm{~kg} / \mathrm{ha}) \\ \text { design in each cultivar } & \text { tolyfluanid }(1.25 \mathrm{~g} / \mathrm{litre}) \\ \text { (four rows of eight } & \\ \text { trees with two guard } & \\ \text { rows separating the } & \\ \text { two cultivars) } & \end{array}$

'Braeburn' 2006-07:

18 and 31 May 2006,

'Sciros'/Pacific Rose ${ }^{\mathrm{TM}}$ :

9 and 31 May 2006,

both 16 years two cultivars)

\author{
Havelock North, Hawke's Bay \\ 'Fuji' and 'Royal Gala' \\ 2006-07: \\ 17 and 24 May 2006, \\ both 17 years \\ Two replicates in a \\ randomised block \\ design in each cultivar \\ (six rows of six trees \\ with a $20 \mathrm{~m}$ wide \\ grass area separating \\ the cultivars.) \\ captan (0.96 ml/litre) \\ myclobutanil (0.048 g/litre)
}

The fungicide programmes used during the following spring and summer were suited to the scab risk in each region and adhered to New Zealand Integrated Fruit Production guidelines (Anon. 2006). In 2006-07 in Nelson, 'Royal Gala' and 'Braeburn' received fungicide applications on 19 dates and 'Sciros'/Pacific Rose ${ }^{\mathrm{TM}}$, on 17 dates, at about weekly intervals from budburst in September until late November, then at 2-4 week intervals until pre-harvest. In 2007-08 in Nelson 'Royal Gala' similarly received applications on 16 dates. In Hawke's Bay in 2006-07, 'Royal Gala' and 'Fuji' similarly received fungicide applications on 11 dates.

The urea applications made to the Nelson trials were each of a $2.5 \%$ urea solution, giving a total of $100 \mathrm{~kg}$ urea/ha. This amount has been shown to reduce ascospore 
production (Beresford \& Wood 2000) without causing phytotoxicity to apple buds (Wood \& Beresford 2000).

The percentage incidence of scab was assessed on the leaves of terminal extension shoots and on fruit (Beresford \& Manktelow 1995) during mid-season fruit development in December, and again between February and April, just before harvest for each cultivar. Leaves on 10 shoots on each of 4-5 trees in the centre of each experimental plot and 150-200 fruit (Nelson) or 400 fruit (Hawke's Bay) were assessed non-destructively.

Leaf and fruit scab incidence data were analysed for treatment effects by analysis of variance, using the general linear model facility in Minitab version 15. Assumptions for analysis of variance were found to be satisfied without transformation.

\section{RESULTS}

In the 2006-07 Nelson 'Royal Gala' trial there was a significant autumn fungicide treatment effect on leaf scab incidence in December and February and on fruit scab in December, but no significant effect on fruit scab in February (Table 2). Tolyfluanid significantly reduced scab compared with the control for all assessments in which an overall significant treatment effect occurred. Urea application resulted in significant mid-season (December) reductions in leaf and fruit scab. Myclobutanil application resulted in a significant reduction in leaf scab in February, but not in December, and not on fruit in December.

In the 2007-08 Nelson 'Royal Gala' trial, much less scab developed than in 2006-07 and no significant effects from the treatments applied in autumn were detected (Table 2).

In the Nelson 'Braeburn' trial in 2006-07 very high levels of scab developed. The only significant effect from autumn fungicides was that urea reduced fruit scab compared with the control in December, and tolyfluanid reduced fruit scab compared with the control in March (Table 3). In 'Sciros'/Pacific Rose ${ }^{\mathrm{TM}}$, the incidence of scab was lower than in 'Braeburn' and no significant treatment effects were observed.

TABLE 2: Scab incidence (\%) on leaves and fruit of 'Royal Gala' in Nelson in relation to autumn-applied fungicides. Scab was assessed on 7 December 2006 and 20 February 2007 (pre-harvest) and on 3 December 2007 and 19 February 2008 (pre-harvest).

\begin{tabular}{|c|c|c|c|c|}
\hline \multirow[b]{2}{*}{ Treatment } & \multicolumn{2}{|c|}{ Leaves (\% scab) } & \multicolumn{2}{|c|}{ Fruit (\% scab) } \\
\hline & Dec & Feb & Dec & Feb \\
\hline \multicolumn{5}{|l|}{ Motueka, Nelson 2006-07 } \\
\hline 1. Control & $0.9 \mathrm{~b}^{1}$ & $26.1 \mathrm{~b}$ & $9.7 \mathrm{~b}$ & 5.5 \\
\hline 2. Urea & $0.1 \mathrm{a}$ & $7.0 \mathrm{ab}$ & $4.2 \mathrm{a}$ & 4.0 \\
\hline 3. tolyfluanid & $0.2 \mathrm{a}$ & $2.6 \mathrm{a}$ & $2.7 \mathrm{a}$ & 5.5 \\
\hline 4. myclobutanil & $0.6 \mathrm{ab}$ & $5.2 \mathrm{a}$ & $5.4 \mathrm{ab}$ & 7.5 \\
\hline P-value & $\mathrm{P}<0.01$ & $\mathrm{P}<0.05$ & $\mathrm{P}<0.05$ & $\mathrm{~ns}^{2}$ \\
\hline \multicolumn{5}{|l|}{ Motueka, Nelson 2007-08 } \\
\hline 1. Control (no autumn fungicide) & 0 & 0 & 0.6 & 1.3 \\
\hline 2. Urea & 0 & 0 & 2.9 & 1.0 \\
\hline 3. captan & 0 & 0 & 1.9 & 1.1 \\
\hline 4. Petrochem $®$ Urea + captan & 0 & 0 & 1.1 & 0.6 \\
\hline $\mathrm{P}$-value & - & - & $\mathrm{ns}$ & ns \\
\hline
\end{tabular}

${ }^{1}$ Means within a column followed by the same letter are not significantly different according to $\operatorname{LSD}(\mathrm{P}=0.05)$.

${ }^{2} \mathrm{~ns}=$ not significant. 
TABLE 3: Incidence of apple scab (\%) on leaves and fruit of 'Braeburn' and 'Sciros'/Pacific Rose ${ }^{\mathrm{TM}}$ in Nelson on 7 December 2006 and 15 March (pre-harvest) 2007, in relation to autumn-applied fungicides.

\begin{tabular}{|c|c|c|c|c|c|c|c|c|}
\hline \multirow[b]{3}{*}{ Treatment } & \multicolumn{4}{|c|}{ Leaves (\% scab) } & \multicolumn{4}{|c|}{ Fruit (\% scab) } \\
\hline & \multicolumn{2}{|c|}{ 'Braeburn' } & \multicolumn{2}{|c|}{$\begin{array}{c}\text { 'Sciros'/ } \\
\text { Pacific Rose }\end{array}$} & \multicolumn{2}{|c|}{ 'Braeburn' } & \multicolumn{2}{|c|}{$\begin{array}{c}\text { 'Sciros'/ } \\
\text { Pacific Rose }\end{array}$} \\
\hline & Dec & Mar & Dec & Mar & Dec & Mar & Dec & Mar \\
\hline 1. Control & 0.5 & 24.5 & 0 & 1.0 & $16.4 b^{1}$ & $20.0 \mathrm{~b}$ & 3.8 & 9.5 \\
\hline 2. Urea & 0.2 & 16.2 & 0 & 0.3 & $4.8 \mathrm{a}$ & $15.0 \mathrm{ab}$ & 4.3 & 5.5 \\
\hline 3. tolyfluanid & 0.4 & 6.7 & 0 & 0.0 & $11.0 \mathrm{ab}$ & $8.5 \mathrm{a}$ & 3.4 & 4.0 \\
\hline $\mathrm{P}$-value & $\mathrm{ns}^{2}$ & ns & - & ns & $\mathrm{P}<0.01$ & $\mathrm{P}<0.05$ & ns & $\mathrm{ns}$ \\
\hline
\end{tabular}

${ }^{1}$ Means within a column followed by the same letter are not significantly different according to $\operatorname{LSD}(\mathrm{P}=0.05)$.

${ }^{2} \mathrm{~ns}=$ not significant.

In the Hawke's Bay trial in 2006-07, autumn myclobutanil applications resulted in significantly lower incidence of leaf and fruit scab for both 'Royal Gala' and 'Fuji' compared with captan (Table 4). This was shown to be a significant effect when analysed using cultivars as replicates. Because of limited orchard size, this trial did not include a control with no autumn fungicide.

TABLE 4: Incidence of apple scab (\%) on leaves and fruit of 'Royal Gala' and 'Fuji' in Hawke's Bay on 4 December 2006 and pre-harvest 2007, in relation to autumn-applied fungicides.

\begin{tabular}{|c|c|c|c|c|c|c|}
\hline & \multicolumn{3}{|c|}{ Leaves (\% scab) } & \multicolumn{3}{|c|}{ Fruit (\% scab) } \\
\hline & $\begin{array}{l}\text { 'Royal } \\
\text { Gala' }\end{array}$ & 'Fuji' & Mean & $\begin{array}{l}\text { 'Royal } \\
\text { Gala' }\end{array}$ & 'Fuji' & Mean \\
\hline \multicolumn{7}{|c|}{4 December 2006} \\
\hline myclobutanil & 1.4 & 1.5 & 1.4 & 1.2 & 0.7 & 1.0 \\
\hline Captan ${ }^{\circledR}$ & 3.0 & 1.8 & $2.4 * 2$ & 3.2 & 0.9 & $2.1 * * 2$ \\
\hline \multicolumn{7}{|l|}{ Pre-harvest $^{1}$} \\
\hline myclobutanil & 2.0 & 1.9 & 1.9 & 2.5 & 0.9 & 1.7 \\
\hline Captan $\AA$ & 4.8 & 4.1 & $4.4 * *$ & 4.7 & 1.5 & $3.1 *$ \\
\hline
\end{tabular}

'Pre-harvest for 'Royal Gala' = 28 February 2007; for 'Fuji' = 12 April 2007.

${ }^{2}$ Significantly different from myclobutanil at $*=\mathrm{P}<0.05$ or $* *=\mathrm{P}<0.01$.

\section{DISCUSSION}

These field trials showed that fungicides applied to apple trees during leaf fall in autumn can reduce apple scab incidence during the following season. Significant reductions occurred in three out of five comparisons that involved different sites, years and cultivars. Variability in the occurrence of significant reductions may have been partly the result of interference between the relatively small plots used in the trials, as a result of leaves blowing between plots during winter and airborne ascospores blowing 
between plots during spring. These trials may thus have underestimated the true benefits of autumn fungicide applications that would occur in full-sized commercial orchards. Similar variability was found in Holland and in Hungary (Holb et al. 2006), where the effects of autumn and winter sanitation measures, including urea and captan sprays and leaf shredding, were tested. A significant reduction in fruit scab at harvest was only detected in one out of six comparisons over two sites and 3 years.

In the Hawke's Bay trial, myclobutanil significantly reduced leaf and fruit scab compared with captan. In a separate study on the effects of autumn-applied fungicides on V. inaequalis ascospore production (Wood et al. 2008), myclobutanil was shown to significantly reduce numbers of ascospores produced during spring in the same trial. In the Nelson 'Royal Gala' trial, myclobutanil did not consistently reduce scab compared with the control, which was surprising as myclobutanil is generally regarded as a highly effective fungicide against apple scab. This suggests that there may be reduced sensitivity to myclobutanil at that Nelson site. Myclobutanil belongs to the demethylation inhibitor (DMI) group of fungicides and is considered to be at risk from resistance development in New Zealand (Martin et al. 2005; http://www.nzpps.org/resistance/dmi.php). The autumn application of myclobutanil, or any other DMI fungicide, should be avoided in commercial orchards to minimise resistance risk. Conversely, captan and tolyfluanid are not considered to be at risk from resistance development and these fungicides would be suitable for autumn application. Autumn-applied urea had a variable effect in reducing scab the following season. Urea application resulted in significantly less scab than the control in three out of five comparisons in which significant treatment effects from autumn fungicides occurred.

Use of synthetic fungicides in autumn to reduce apple scab risk the following season appears to be a promising strategy to reduce the risk of fungicide residues on fruit. The possibility of using a greater number of autumn applications, or higher application rates, could lead to greater reductions in scab and these should be further investigated. The autumn fungicide strategy described in this paper differs from standard approaches to apple scab sanitation in that it uses synthetic fungicides. Standard approaches, such as urea, leaf removal, leaf destruction or ground covering, either have high associated costs or cause specific environmental problems that may be even less desirable than the use of synthetic fungicides.

\section{ACKNOWLEDGEMENTS}

We wish to thank Pipfruit New Zealand Inc. for funding this study and Stephen Hoyte, Pia Reinlander and Anne Gunson for helpful comments during preparation of the manuscript.

\section{REFERENCES}

Anon. 2006. New Zealand Pipfruit Integrated Fruit Production Manual, Part B Disease Management. Pipfruit New Zealand Inc., Hastings, New Zealand. 40 pp.

Beresford RM, Manktelow DWL 1995. Methods for disease assessment in apples, including growth stages, leaf emergence, black spot and powdery mildew. New Zealand Plant Protection 48: 89-94.

Beresford RM, Wood PN 2000. Autumn-applied urea and other compounds to suppress Venturia inaequalis ascospore production. New Zealand Plant Protection 53: 382-386.

Holb IJ, Heijne B, Jeger MJ 2006. Effects of integrated control measures on earthworms, leaf litter and Venturia inaequalis infection in two European apple orchards. Agriculture, Ecosystems and Environment 114: 287-295.

MacHardy WE 1996. Apple scab biology, epidemiology and management. APS Press, American Phytopathological Society, St Paul, Minnesota, USA. 545 pp. 
Martin NA, Beresford RM, Harrington, KC ed. 2005. Pesticide Resistance: Prevention and Management Strategies 2005. New Zealand Plant Protection Society Inc., Hastings, New Zealand. 166 pp.

Wood PN, Beresford RM 2000. Avoiding apple bud damage from autumn-applied urea for black spot (Venturia inaequalis) control. New Zealand Plant Protection 53: 387-392.

Wood PN, Beresford RM, Taylor TJ 2008. Suppression of Venturia inaequalis (apple $\mathrm{scab}$ ) ascospore production using autumn applied fungicides. New Zealand Plant Protection 61: 54-58. 